\title{
LATINOS, AFRICAN AMERICANS AND THE COALITIONAL CASE FOR A FEDERAL JOBS PROGRAM
}

\author{
Alan A. Aja \\ Brooklyn College, CUNY \\ William Darity, Jr. \\ Duke University \\ Darrick Hamilton \\ The New School
}

In May 1978, amidst a period marked by high inflation and economic decline, the United States Commission on Civil Rights released a report evaluating the adequacy of the Department of Labor's unemployment data on the Hispanic population. Previously, statistical data on the 11.3 million United States Hispanics had been scarce, making it difficult for advocacy groups and policymakers to understand the social and economic reality of the nation's fastest growing ethnic group. Thus, pursuant to Public Law 94-311 - which demanded improved collection and analysis of Hispanic unemployment data - the commission began to more fully document the sobering economic reality Latino leaders and organizations were arguing required an adequate policy prescription. ${ }^{1}$

Specifically, the agency estimated that for most of the 1970s, the average Latino unemployment rate hovered around 10 percent, having reached a high of 12.2 percent in $1975 .^{2}$ Among Hispanic sub-groups, Puerto Ricans and Mexicans on average had higher unemployment rates throughout the decade than Cubans, the third largest Latino group. But by 1977 , the differences generally were of marginal significance; at that point all three groups had rates that hovered around 10 percent. Other related indicators, the Commission noted, showed that only 40 percent of Latinos twenty-five years old or older had completed high school, median income stood at $\$ 10,200$ (two-thirds of the median income of nonLatino whites at the time), and one quarter of Latino families lived below the poverty level. ${ }^{3}$

1 See US Commission report, 1978, p. 1.

2 "Improving Hispanic Unemployment Data: The Department of Labor's Continuing Obligation," May 1978, US Commission on Civil Rights.

3 US Commission on Civil Rights, 1978, also see Bureau of Census data (1977). 
Meanwhile, the decade-old Congressional Black Caucus (CBC), concerned over consistently high unemployment rates in the African American community, already had been leading the way in addressing the spiraling economy's disproportionate impact on historically marginalized groups. Inspired by an earlier (1972) report by members of the National Economic Association (NEA) (then the Caucus of Black Economists) which called for sustained full employment as a fundamental human right (Darity, Jr. 2010), one of the CBC's founding members (and representative of a predominantly low-income, black and Latino California district), Congressman Augustus F. Hawkins, joined long-time ally of organized labor Senator Hubert Humphrey (MN) to write the Full Employment and Balanced Growth Act, popularly known as the Humphrey-Hawkins Act of 1978. ${ }^{4}$ After months of negotiations, a coalition of labor unions, clergy, advocacy groups, along with support from the $\mathrm{CBC}$ and the newly formed Congressional Hispanic Caucus (CHC), helped to better position the act on the legislative agenda. Subsequently, it was passed by Congress and signed into law by President Carter on October 27, 1978.

Based on the tradition of Keynesian economics, the act empowered the government to spend proactively in the private sector to increase consumer demand, with the primary goal of achieving full employment. The act required all federal programs and policies to work toward achieving a 3 percent adult and 4 percent overall jobless rate within five years and inflation rates of 3 percent by 1983 and eliminating unemployment in its entirety by 1988 (Schantz, 1979). But over time, the overriding political concern with inflation became the primary bi-partisan focus, while the struggle against unemployment evaporated as a priority (Ginsburg, 2011). This evaporation rendered invisible a lesser-known and most crucial provision of the act: that if the private sector failed to respond adequately in reducing unemployment, the public sector (read: federal government) would be responsible for the direct creation of those missing jobs.

Today, more than thirty-five years later, the United States supposedly lies at the edge of the "Great Recession," triggered largely by the post-2006 mortgage-lending crisis. Despite claims of a modest economic recovery, mass long-term unemployment remains high for the skilled and unskilled alike, with a disproportionate impact on African Americans and Latinos. According to the Bureau of Labor Statistics (November, 2014), while the overall United States unemployment rate stood most recently at

4 For instance, while the unemployment rate hovered between 12 and 14 percent during the mid 1970s, by 1978 rates widened between blacks and whites dramatically, with a "black and other race" unemployment rate 2.4 times higher than the rate for whites. (Bureau of the Census 1979) 
5.8 percent, the black and Latino unemployment remained significantly higher, estimated at 11.9 percent and 6.6 percent respectively (compared to the relatively lower 4.9 percent figure for whites). But this does not provide the entire picture. The labor force participation rate (the percent of both employed and unemployed sixteen and older in the labor force) has declined dramatically since the "Great Recession," especially for people of working ages 25-54 years old. In November of 2014, the labor force participation rate was calculated at 62.8 percent, a marked decline from the general average of 66 percent during 2007 and a figure only marginally higher than the previous low of 62.7 percent during February of 1978, economic realities that served as impetus for the passing of the Humphrey-Hawkins Act in the first place. ${ }^{5}$

To underscore our point further, these figures should also be viewed alongside the before-and-after impact of the Great Recession on specific metropolitan areas, which display dramatically higher unemployment rates for blacks and Latinos compared against their groups' respective national averages. According to two separate studies published by the Economic Policy Institute (2010), thirty-one metro areas recorded unemployment rates reaching 20 percent for blacks in cities like Detroit, Milwaukee, Las Vegas and Minneapolis, while a study of thirty-eight cities yielded similarly high rates for Hispanics in cities including Providence, Hartford and Fresno. These figures, the EPI aptly notes, rival the peak national unemployment rate during the Great Depression of the 1930s (Austin, 2011).

However, we must note that these disparities are not simply the effect of the "Great Recession," nor are they recent statistical patterns. Indeed, the overall unemployment rate for African-Americans historically has been roughly double that of whites and for Latinos roughly 1.5 times greater than the white rate (Bureau of Labor Statistics 2010). Despite these disparities, and the irony that black and Latino unemployment rates are nearly at the same levels when the Humphrey-Hawkins Act of 1978 was passed, only recently has discussion resumed over a basic right to employment in Washington, D.C.

For close to forty years, the Full Employment and Balanced Growth Act of 1978 has existed, de facto, as an unfunded mandate. In 2011, United States Representative John Conyers, Jr. (D-MI) introduced a bill (HR-1000) entitled the Humphrey-Hawkins 21st Century Full Employment and Training Act to provide the financing and structure to fulfill the full employment goal of the original legislation. Calling it a " 21 st century New Deal," in which the federal government "plays a major role in

5 See Tables and excel documents provided by the Bureau of Labor Statistics, Department of Labor, available at: http://data.bls.gov/timeseries/LNS11300000 (December 10, 2014). 
getting Americans back to work," Conyers' bill invokes the spirit and intent of the 1978 legislation by creating two complementary trust funds, one that funds states and localities for specific job-creating activities, the other directed toward job training programs for unskilled workers (Conyers, Jr., 2011).

While there has been no mention of a federal jobs program by President Obama or his administration, the central premises behind Conyers' act only recently have begun to gain traction amongst media and policymakers. In his widely read article recently published in Rolling Stone (January 3, 2014), Jesse Myerson argued that given the adverse impact of the Great Recession on "new millennials," young people should support a set of five economic reforms; the first he listed is a federal job guarantee.

After Myerson's article drew criticism from political pundits and social media users, the Huffington Post commissioned a scientific poll to measure public opinion about a federal job guarantee. The poll found that 47 percent of 1,000 Americans sampled supported a law allowing the government to provide jobs for Americans who could not find work in the private sector, while 41 percent disagreed and 12 percent were unsure. Overall, this suggests modest but general support for a federal jobs guarantee. When broken down by ethnic group, the numbers are more telling. Black support for such a measure polled the highest at 67 percent (14 percent against, 19 percent unsure), Latino support stood at 52 percent (35 percent against, 13 percent unsure) while non-Hispanic white support was slightly weaker with 43 percent in support (45 percent against, 12 percent unsure).

To date, Conyers, a long-time prominent member of the Congressional Black Caucus (CBC), has received some support for the legislation from members of the Congressional Hispanic Caucus (CHC), several of whom are co-sponsors of his bill. Meanwhile, according to his office, the legislation is beginning to yield interest from Latino civil rights and advocacy groups like the National Council of La Raza (NCLR). This is an important development considering the concerted energies and focus by Hispanic groups on passing comprehensive immigration reform while countering the dangerous culture of austerity economics (spending cuts) in Washington.

Given the aforementioned support by African Americans and Latinos alike, we believe that a permanent, full-employment policy consistent with the ideals of the Humphrey-Hawkins Act of 1978 not only would serve as a direct alternative to austerity economics (see Aja, Bustillo, Darity, Jr. and Hamilton, 2013), but also address longstanding patterns of racial and inter-group inequality. In short, a federal job guarantee would remove the threat of unemployment and ensure that the opportu- 
nity to work for a livable wage and decent pay is a basic right of citizenship for all Americans (Darity, 2010). ${ }^{6}$

If the National Investment Employment Corps were implemented, pay would range from a minimum of $\$ 23,000$ to a maximum of $\$ 80,000$, each job also providing benefits (including medical coverage and retirement support), opportunities for advancement, on-the-job training, and professional development. ${ }^{7}$ Much like Franklin Delano Roosevelt's Workers Progress Administration (WPA), a national program of job assurance will provide meaningful employment in a variety of "public works" projects. It could potentially serve as the stimulus for the types of innovative, green technologies the president has touted frequently, necessary "green jobs" considering the adverse effects of climate change. States and municipalities could develop inventories of needed jobs for all who are able to work, matching skilled and unskilled laborers alike with full employment opportunities. ${ }^{8}$

In a recent March 2013 report, the American Society of Civil Engineers (ASCE) gave the country a grade of D+ on its physical infrastructure, only a slight improvement from a grade of a D in 2009. ${ }^{9}$ The report indicated that a total investment of $\$ 3.6$ trillion is required by 2020 , streams of funding necessary in order to deal with the backlog of overdue maintenance across our infrastructure systems. Thus a federal job program would address physical and human infrastructure needs including the building, repair, and maintenance of bridges, damns, roads, parks, museums, mass transit systems, school facilities, health clinics, and child care centers, giving priority to the most urgent projects to aid the most distressed communities.

Under Representative Conyers' bill, a federal jobs program would be funded through a slight tax increase on the top percentile of earners, a type of revenue transfer that citizens increasingly support. In New York City, for example, Mayor Bill DeBlasio was elected in late 2013 on an anti-austerity, populist agenda that called for the expansion of universal

6 For previous examples of federal job guarantee programs, see Harvey (2000) and Wray (2008).

7 This is an updated analysis of the policy proposal as outlined in William Darity, Jr. and Darrick Hamilton (2012). Also see for reference the following news article: http://busi ness.nbcnews.com/_news/201 1/1 1/28/9067808-fed-lent-banks-nearly-8-trillion-during-crisisreport-shows?chromedomain=investigations

8 Initial outline of the federal jobs guarantee, framed in the context of growing wealth inequality and labor market discrimination, is described in Darity, Jr. (2010) and Darity, Jr. and Hamilton (2012), also see Aja, Bustillo, Darity, Jr. and Hamilton (2013) for discussion of the program as a necessary alternative to austerity politics.

9 In fact, the report maintains that bridges in urban areas are decaying more rapidly than those in rural areas, while funding streams are not sufficient enough to maintain and improve them. It also expressed concern for the aviation sectors and the country's dams. See 2013: Report for America's Infrastructure, ASCE, March 2013. Available at: http://www.inf rastruc turereportcard.org/a/documents/2013-Report-Card.pdf 
child care programs through a modest, minimal tax increase on the wealthiest residents of the state. Similarly - given the Obama-Romney 2012 presidential campaign position difference on allowing the George W. Bush presidential administration tax cuts to expire for those earning above $\$ 250,000$ - Obama's election victory may serve as evidence of a national voter sentiment of this type of revenue transfer. But a permanent, nation-wide NEIC would essentially pay for itself, given that the income paid to the employees of the NIEC would not only restore tax bases at the state and municipal levels, alleviating current budget crises.

Furthermore, we calculate that the cost of a National Investment Employment Corps (NIEC) would be less than the first stimulus package enacted by Congress and vastly less than the $\$ 10-30$ trillion awarded by the Federal Reserve to the very same investment banking community that caused the economic crisis in the first place (see Aja, Bustillo, Darity, Jr. and Hamilton, 2013). A back of the envelope calculation indicates that if 15 million persons - the total unemployed at the trough of the Great Recession - were employed at average cost of $\$ 50,000$ per annum per person (salaries, benefits, training, materials and equipment), a high estimate of the total expense of the program would be $\$ 750$ billion (Darity, Jr. and Hamilton, 2012). ${ }^{10}$

Consider that in 2011 alone, federal antipoverty programs (Medicaid, unemployment insurance, etc.) cost approximately $\$ 746$ billion (Wasson 2012). A federal job guarantee would make it possible to reduce drastically current antipoverty expenditures and is, by comparison, far more productive in its deployment of both physical and human capital development. Hence, the net expense of a job guarantee program could also be minimal given the potential of cost savings from other social programs. With the federal government serving as employer of last resort, unemployment compensation along with antipoverty program funding for free and reduced lunch subsidies and food stamps could be reduced since a job guarantee works to eliminate both working and jobless poverty simultaneously.

The NEIC also would be a better source of job creation than the Keynesian-based indirect incentive effects of stimulus measures and tax incentive strategies aimed at encouraging the private sector to provide jobs. After all, a federal job guarantee serves as a direct mechanism for job creation while also triggering a multiplier stimulus effect across a wide panoply of activities that take place in the economy. The private sector would benefit in a myriad of ways, not just by stabilizing consumption demand, but also through vertical linkages of sales of supplies

10 This is less than the first $\$ 787$ billion stimulus package and also much less than the first round of investment bank bailouts ( $\$ 1.3$ trillion). See Aja, Bustillo, Darity, Jr. and Hamilton (2014) and Aja, Bustillo, Darity, Jr. and Hamilton (2013). 
and materials to the NIEC for public projects. This also could create advantages for black and Latino-owned businesses, while leverage for unions also would be created, since the jobs offered by the NIEC would set an effective minimum floor on the quality of employment.

Furthermore, one might expect that the existence of an NIEC would incentivize profit-seeking employers to demand less costly undocumented workers who would not qualify for a federal job guarantee. While it is likely that employers would tend to pay them less than the floor on wages provided by the job guarantee, over time, we would expect the economy-wide rise in wages associated with the federal job guarantee workers would even bid up wages -at least marginally - for group whose labor market status is more vulnerable, such as undocumented immigrants. Furthermore, since permanent residents are governed under the same labor laws as United States citizens, the same protections of a federal right to work for decent pay granted by a federal job guarantee would be extended to this group as well. This would have additional positive impacts on the economic livelihoods of "mixed-status" Latino households (those who live in arrangements where one household member may hold a legalized status while others are undocumented), given that permanent residents could apply for work under the federal job guarantee. ${ }^{11}$

Other benefits include the potential reduction or elimination of a number of market interventions like minimum wage laws, financial regulation, and associated enforcement expenses. Minimum wage laws no longer would be needed since the minimum salary offered by the NIEC would set the floor on the wage standard. Concerns around strengthening and constantly updating financial regulation to keep up with constantly evolving economically and environmentally harmful private sector products and practices aimed at eluding regulation would be reduced. The presence of a job guarantee would mitigate the adverse effects of fluctuations in speculative investment markets on personal employment and income for the public at large.

To be clear, a federal job guarantee is not meant to act as a temporary program contingent upon emergency conditions. Instead, it will function as a permanent, automatic stabilizer. The number of persons put to work in the NIEC will rise during downturns and fall during upswings. Thus, like the cost of the program, it will expand and contract counter-

11 We understand that the coalitional effort to pass comprehensive immigration reform is of utmost urgency and importance, especially for the Latino community, but we believe that there are no substantive policy specific reasons why such efforts and focus are not largely independent of those needed to pass a federal job guarantee. We support a comprehensive immigration reform package that includes pathways to citizenship for undocumented workers currently residing in the United States. Clearly, such reform would disproportionately benefit both Latino and black, albeit to a lesser extent than Latino, workers. 
cyclically. In addition, it would produce the structural change in the United States economy away from the generation of low wage jobs and toward more moderate and high wage jobs.

The program would guarantee employment for members of stigmatized populations subject to discriminatory employment exclusion. Devah Pager's audit study in Milwaukee, Wisconsin and in New York City, for example, revealed that among males of comparable age and employment qualification, white applicants received more employment callbacks than their black counterparts. Even more alarming, the study also found that whites with criminal records were slightly more likely to get call backs than black males with no criminal record (Pager 2003). Indeed, even among white males alone, having a criminal record reduced the odds of receiving an employment call back by half. It is notable that one set of these audits took place in Wisconsin, a state that outlaws employer use of criminal records as a criterion for employment in most jobs.

In another example, using personnel data from a large United States retail firm, Guiliano, Levine, and Leonard (2008) undertook an examination of whether the race of the hiring manager affects the racial composition of new hires, finding significant differences between the hiring patterns of non-black managers and black managers, with non-black managers hiring more whites and fewer blacks than black managers. Also, Bureau of Labor Statistics (BLS) indicates that among 18-25 year olds, white high school dropouts had an unemployment rate lower than blacks that have completed some college. The evidence suggests that even when blacks are able to avoid incarceration and acquire education they are employed at lower rates than their white formerly incarcerated and lower educated counterparts.

Globally, programs similar to a federal jobs guarantee have proven to be effective. Argentina's Plan Jefelas de Hogar Desocupados program, initiated in 2002, provides a payment of 150 pesos per month to a head of household for a minimum of 4 hours of daily work in community services, small construction, or maintenance services. The program provided jobs to 2 million workers, with indigence rates among participating households falling by nearly 25 percent and the unemployment rate dropping from 21.5 percent in May 2002 to 15.6 percent in May 2003 (Tcherneva and Wray 2005), while the program's multiplier effect conservatively was estimated at 2.57 (Harvey 2007).

In another example, India's National Rural Employment Guarantee Scheme, which was implemented in 2006, guarantees rural households the legal right to be employed up to 100 days a year. For individuals, the program entitles them to receive wages if no work is made available to them within two weeks of an application. Liu and Deiniger (2010) esti- 
mate that the short-term effects of the Indian program on participating households were positive and greater than program costs.

At present, non-white racial and ethnic groups, who chronically are subjected to higher unemployment rates, suffer the most from austerity policies and federal indifference toward full employment policy. To reverse this, we need a renewed inter-group coalition, organized in the spirit of the late 1970s, reminding the President and Democratic members of Congress of the overwhelming support they received from African Americans and Latinos during the two previous elections. A federal job guarantee not only would address long-standing unjust and discriminatory barriers that keep large segments of stigmatized populations out of the labor force, but also would reverse the rising tide of inequality for workers in general by strengthening their labor market bargaining power and eliminating the threat of unemployment for all Americans. Finally, the program would create productive physical and human capital investment jobs that would reverse the trend of a crumbling and depreciating public infrastructure, which would have a long-standing stimulus effect similar to the benefits of the massive public investment undertaken during the Great Depression.

\section{REFERENCES}

Aja, Alan, Daniel Bustillo, William Darity, Jr. and Darrick Hamilton, "From a Tangle of Pathology to a Race-Fair America," Dissent: Quarterly of Politics and Culture, Summer, 2014.

Aja, Alan, Daniel Bustillo, William Darity, Jr. and Darrick Hamilton. "Jobs Instead of Austerity: A Bold Policy for Economic Justice." Social Research: An International Quarterly 80.3: 781-94, 2013.

Aja, Alan, William Darity Jr. and Darrick Hamilton. "Don't Cut, Invest! Why the Obama Administration Should Support a Federal Jobs Guarantee Program!” The Huffington Post, March 12, 2013.

Bureau of the Census. 1979. "The Social and Economic Status of the Black Population in the United States, An Historical View, 17901978."

Bureau of Labor Statistics. (2011). "Unemployment rates by race and ethnicity, 2010: The Editor's Desk: U.S. Bureau of Labor Statistics." Last modified October 5, 2011. <http://www.bls.gov/opub/ ted/2011/ted_20111005.htm>.

Conyers, Jr., John, "H.R. 1000, The "Humphrey-Hawkins Full Employment and Training Act," http://www.johnconyers.com/hr-1000-hum phrey-hawkins-full-employment-and-training-act\#.U0VEqcecA7A Accessed January 15, 2014. 
Darity, Jr. “A Direct Route to Full Employment," Review of Black Political Economy, 2010, 37 (3, 4): 179-81.

Darity Jr., William and Darrick Hamilton. 2009. "Race, wealth and intergenerational poverty: there will never be a post-racial America if the wealth gap persists." The American Prospect 20(7).

Darity Jr., William and Darrick Hamilton. 2012. "Bold Policies for Economic Justice. "Review of Black Political Economy. 39(1):79-85.

Diette, Timothy, Arthur Goldsmith, Darrick Hamilton, and William Darity, Jr. 2012. "Causality in the Mental Health-Unemployment Relationship." In Reconnecting to Work: Policies to Mitigate LongTerm Unemployment and Its Consequences, edited by Lauren Appelbaum. W.E. Upjohn Institute for Employment Research.

ECLAC. 2012. "Statistical Yearbook for Latin America and the Caribbean." December 2012. <http://www.cepal.org/cgi-bin/getProd.asp? $\mathrm{xml}=/$ publicaciones/xml/4/48864/P48864.xml\&xsl=/tpl-i/p9f.xsl\& base $=/$ tpl/top-bottom.xsl $>$.

Eyraud, Luc and Anke Weber. (2013). "The Challenge of Debt Reduction During Fiscal Consolidation." Working Paper No. 13/67, International Monetary Fund. March 8.

Ginsburg, Helen Lachs. 2011. "Historical Amnesia: The HumphreyHawkins Act, Full Employment and Employment as a Right." The Review of Black Political Economy. December 7.

Giuliano, Laura, David I. Levine, and Jonathan Leonard. 2009. "Manager Race and the Race of New Hires." Journal of Labor Economics 27(4): 589-631.

Hamilton, Darrick and William Darity, Jr. 2010. "Can 'Baby Bonds' Eliminate the Racial Wealth Gap in Putative Post-Racial America?" Review of Black Political Economy 37(3, 4):207-216.

Harvey, Philip. 2007. "Argentina's Jefes De Hogar Program." Human Sciences Research Council, Pretoria, South Africa.

Harvey, Philip. "Direct Job Creation," In: Warner, A., Forstater, M., Rosen SM, editors. The commitment to full employment: the economics and social policy of William S. Vickrey, Armonk: M.E. Sharpe; 2000, p. 35-54.

Huffington Post. 2013. "Sequester Could Cost US 750,000 Jobs, CBO Director Douglass Elmendorf says." Last modified February 13, 2013. <http://www.huffingtonpost.com/2013/02/13/sequester-jobcuts_n_2678701.html>. 
Isaacson, Adam. 2013. Washington Office of Latin America, http:// thisisadamsblog.com/post/41220961868/take-the-annual-income-ofthe-wealthiest-20, January 22, 2013.

Isidore, Chris. 2012. "Corporate Profits hit record as wages get squeezed." CNN money. Last modified December 4, 2012. <http:// money.cnn.com/2012/12/03/news/economy/record-corporate-pro fits/>.

Jelinek, Pauline. 2013. "How the Sequester Will Affect You." The Huffington Post. Last modified March 2, 2013. <http://www.huffington post.com/2013/03/03/sequester-affects-you_n_2801365.html>.

Knight, Heather. 2013. "SF Homeless Families' Long Housing Wait." SF Gate. Last modified March 20, 2013. <http://www.sfgate.com/ bayarea/article/SF-homeless-families-long-housing-wait-4372052 .php>.

Liu, Y. and K. Deininger. 2010. "Poverty Impacts of India's National Rural Employment Guarantee Scheme: Evidence from Andra Pradesh." Paper presented at the Agricultural \& Applied Economics Association Meeting. July 25-27.

Myerson, Jesse. "Five Economic Reforms Millennials Should be Fighting For," Rolling Stone, January 3, 2014.

Markee, Patrick. (2013). "State of the Homeless 2013." Coalition for the Homeless. Last modified: March 5, 2013. <http://www.coalitionfor thehomeless.org/pages/state-of-the-homeless-2013>.

Pager, Devah. 2003. "The Mark of a Criminal Record." American Journal of Sociology 108(5): 937-975.

Schantz, Harvey L. 1979. "The Evolution of Humphrey-Hawkins." Policy Studies Journal 8(3): 368-377.

Schneider, Howard. 2013. "An Amazing Mea Culpa From the IMF's Chief Economist on Austerity." The Washington Post. Last modified January 3, 2013. <http://www.washingtonpost.com/blogs/ wonkblog/wp/2013/01/03/an-amazing-mea-culpa-from-the-imfschief-economist-on-austerity/>.

Shapiro T., T. Meschede, and S. Osoro. 2013. "The Roots of the Widening Racial Wealth Gap: Explaining the Black-White Economic Divide." Brandeis University: Institute on Assets and Social Policy.

Swanson, Emily, 2014. "Here's what People Really Think of Rolling Stone's 5 Reforms for Millennials," The Huffington Post, January 13, 2014. 
Taylor, P., R. Kochhar, and R. Fry. 2011. "Wealth gaps rise to record highs between whites, blacks and Hispanics," Washington: The Pew Hispanic Center.

Tcherneva, Pavlina and Randall L. Wray. 2005. "Is Argentina's Job Creation Project Jefes De Hogar a True Employer of Last Resort Program?" Working Paper 43, Center for Full Employment and Price Stability, University of Missouri-Kansas City.

Wasson, Erik. 2012. "Study shows 33 percent spending increase in federal poverty programs." The Hill. Last modified October 18, 2012. $<$ http://thehill.com/blogs/on-the-money/budget/262745-studyshows-33-percent-increase-in-federal-poverty-programs->.

Woo, B., I. Rademacher, and J. Meier. 2009. Upside Down: The $\$ 400$ Billion Federal Asset-Building Budget. CFED and The Annie E. Casey Foundation.

Wray, Randall. "Job Guarantee." In Darity, Jr. W. editor, International Encyclopedia of Social Sciences, Vol. 4, Detroit. Thomas Gale (Macmillan References USA): 2008, p. 204-206.

Yoder, Eric. 2012. "Federal Workforce Reflects Broader Changes." The Washington Post. Last modified June 2, 2012. 